\title{
Process parameters for cylindrical deep drawing components
}

\begin{abstract}
Sheet metal forming is one of the most important manufacturing processes in today's industries, either to produce semi-finished or finished products. The demand for rapid, lowcost die fabrication and modification technology is greater than ever in sheet metal forming industry. Therefore, a great need for the development of both theoretical and experimental engineering methods which enables the problems to be tackled effectively; this is necessary to reduce production cost and to reduce the lead time between design and production. Due to recent development in numerical method technology, finite-element analysis has become one of the important tools in predicting the result of product deformation. With the intention to study the product failure which is the thinning effect, an experimental method has been developed to monitor the metal flow behaviour during the process. With this experiment, the actual product has been drawn with different draw depths, punch and die corner radii on mild steel and aluminium materials. Finally, the product wall thickness and diameter have been measured and data gained were interpreted into graph to visualise the influences of the process parameters such as draw depth, punch and die corner radius on the thinning effect. The results would give tool maker and tool designer guidance for selecting the best punch and die radius size in order to minimise the thinning effect on the drawn product.
\end{abstract}

Keyword: Deep drawing; Metal forming; Sheet metal; Finite-element analysis; Metal stamping 